\title{
Examination of the Motivations for Equity-Based Crowdfunding in an Emerging Market
}

\section{Shaista Wasiuzzaman ${ }^{1}$, Chong Lee Lee ${ }^{2}$, Ong Hway Boon ${ }^{3}$ and Hemalatha Pannir Chelvam ${ }^{4}$}

1 Universiti Teknologi Brunei, School of Business, Bandar Seri Begawan, Brunei, dr.shaist@utb.edu.bn

2 Multimedia University, Faculty of Management, Cyberjaya, Malaysia, Ilchong@mmu.edu.my,

3 Multimedia University, Faculty of Management, Cyberjaya, Malaysia, hbong@mmu.edu.my,

${ }^{4}$ Multimedia University, Faculty of Management, Cyberjaya, Malaysia, 1141125243@student.mmu.edu.my

Received 3 December 2019; received in revised form 3 April 2020; accepted 4 May 2020

\section{Abstract}

This study investigates the various motivations to equity crowdfunding in Malaysia. A total of 169 responses from survey questionnaires are used to test the relationships using Structural Equation Modelling-Partial Least Squares. Investigation into the influence of both intrinsic and extrinsic motivators on the willingness to support equity crowdfunding shows that the financial motive is insignificant in influencing the decision. Among the intrinsic motivators, aesthetic value, emotional value, novelty and trust are highly significant and the desire to be part of a community is the only intrinsic motivator that is insignificant. The willingness to support has a positive influence on the likelihood to invest in equity crowdfunding.

Keywords: Equity crowdfunding, Cognitive values, Affective values, SEM-PLS, Malaysia 


\section{Introduction}

Crowdfunding's popularity as a major source of financing for entrepreneurial ventures has grown over the years [54]. It allows entrepreneurs to raise funds through small contributions from a large number of individuals via an online platform [16]. By year 2015, the number of crowdfunding platforms have increased to more than 1250 within just three years. The global amount raised in 2015 via crowdfunding is reported to be US\$34 billion according to crowdexpert.com (Site 1) and the industry is projected to reach between $\$ 90$ and $\$ 96$ billion by year 2025. Out of the $\$ 34$ billion raised in 2015 , around one-thirds ( $\$ 10.54$ billion) was raised in Asia but funding volume in that region grew at a rate of $320 \%$. Up to $81 \%$ of the total amount raised in Asia was through donation and lending-based platforms [9] and only around $\$ 2.56$ billion was raised through equity crowdfunding (ECF). ECF however experienced the second highest growth at 182\% [20] after lending (or P2P) crowdfunding. The projected compounded annual growth rate (CAGR) for equity-based crowdfunding is expected to be around $32.5 \%$ in the next 5 years [58]. The growth in equity-based crowdfunding depends very much on its supporters - the crowd - hence a study on what motivates the crowd is needed to understand and sustain the growth phenomenon.

Many of the studies on crowdfunding in the past few years have been on crowdfunding in general and not specifically on equity or investment-based crowdfunding. Equity-based crowdfunding is different from donation, reward or lending-based crowdfunding (the three other forms of crowdfunding) because unlike donation or reward-based crowdfunding, the crowd is making an investment decision, not a consumption or donation related one [38]. Additionally, the crowd's incentives and/or compensation are different for the other three types of crowdfunding [38]. A study on what motivates an individual to invest through equity-based crowdfunding will therefore shed light on the possible differences in the decision making process involved in this type of crowdfunding when compared to the other three.

In the past 5 years or so, a number of studies have been conducted on what motivates individuals to invest in crowdfunding (such as [15], [19], [26], [33], [34], [38], [49]) but these studies have mostly focused on developed countries such as the United States and countries in Europe, with hardly any focusing on developing countries. A study of this nature is especially important in developing countries such as Malaysia where SMEs and entrepreneurs make up a large percentage (nearly 97\%) of the business establishments and the funding gap is large [62]. Alternative financing mechanisms such as crowdfunding can therefore play a big role in narrowing the gap. However, the availability of alternative financing mechanisms is not enough as the success of the mechanism in reducing the funding gap depends on the support of the investors who make up the source. Differences in culture, regulatory environment and the level of knowledge about crowdfunding provide the motivations to study this issue in developing countries as these differences influence investor perception and decision making.

Signifcant advancement in technology in recent years has introduced investors to the digital investing platform hence investors may establish new investing behaviors as the result of digital innovation. Digital innovation has expanded the technological capabilities of investors where they spend time and effort to learn the new products. While the technical aspect of digital innovation is important to understand, it is equally important to examine the influence of the aesthetic aspect of the new products on investor behavior and decision making. The aesthetic aspect influence investors' feeling and how attractive the product is to them. For the general public interested in the investment world, equity crowdfunding may be perceived as a black box, i.e. most of them know what it is and how to use it but do not understand the investing mechanism itself and how it works. Technological advancement has been incorporated into many business processes including that of investment. The magic behind digital innovation on an investor's decision making process has directed this study to emphasize on the affective values of investors. Therefore, this study aims to investigate the motivations of investors on equity-based crowdfunding platforms in a developing country such as Malaysia. Specifically, this study focuses on how intrinsic (non-financial) and extrinsic (financial) factors can influence an individual's decision to support a crowdfunded venture and how this decision to support translates into investment in the venture

Malaysia is chosen as the focus because it was one of the first countries in South East Asia to develop a regulatory framework for ECF in year 2016 [60]. In February 2015, the Malaysian Securities Commission (Site 2) released the Guidelines on Regulation of Markets under Section 34 of the Capital Markets and Services Act 2007 to introduce new requirements for the registration of equity crowdfunding (ECF) platforms and provide governance arrangement for the operation of such platforms. At that time, six crowdfunding platforms - PitchIN (founded/launched in year 2012); Alix Global, Crowdo and Eurecca (founded/launched in year 2013); Ata Plus (founded/launched in year 2014) and Propellar CrowdPlus (founded/launched in year 2015). By year 2017, the Securities Commission had approved a total of 12 crowdfunding platforms - six equity-based and six peer-to-peer (P2P) lending. In July 2015, the Malaysian Parliament passed an amendment in the Capital Markets and Services Bill 2015 which allowed crowdfunding to be approved as a practice to raise money from the public to start up a project or venture [18]. Under the Capital Markets and Services Bill 2015, private companies with a paid-up capital of not more than RM5 million and with a strong business plan could fund their ventures through crowdfunding. The amount of capital collected through crowdfunding is limited to a yearly total of RM5 million for these private companies and RM3 million for small and medium enterprises (SMEs). Each retail investor is also only allowed to invest a máximum of RM5,000 for each company and RM50,000 a year for total crowdfunding investment [16]. 
The ECF industry in Malaysia has since seen a steady increase with total funds raised reaching RM21.6 million in 2018, compared to RM8 million in 2016 and RM17.1 million in 2017 [57]. However, the ECF industry in Malaysia is still at a nascent stage of development and its sustainability and growth very much depend on its supporters, i.e. the crowd. Although crowdfunding has gained increasing popularity in Malaysia over the years, public knowledge regarding crowdfunding and their willingness to invest in crowdfunded projects is still low. A report by [20] for the Asian Institute of Finance shows that in year 2015, only around $25 \%$ of the public (especially those having at least a bachelor's degree) was aware of investment crowdfunding and only $11 \%$ had invested in a crowdfunding project before. Thus, awareness regarding crowdfunding does not necessarily translate to investment in crowdfunding as it depends on the perception of the investor and his/her willingness to support crowdfunded ventures. Therefore, there is a need to understand what motivates individuals to support and to eventually invest in ECF in Malaysia in order to ensure its sustainability and to promote its growth.

This study uses survey methodology to collect data on the independent (intrinsic and extrinsic motivations), mediating (decision to support) and the dependent (proportion of portfolio likely to be invested in crowdfunding venture) variables. A total of 169 usable responses is finally used for analysis purposes. Analysis results show that among the intrinsic factors, all factors, except for the desire to be part of a community, are found to have significant positive influences on the decision to support equity crowdfunding. Extrinsic motivation (financial gains) is found to have an insignificant influence on the decision to support. The decision to support relates positively to the proportion an investor is likely to invest in crowdfunding ventures. Interestingly, it is found that individuals with greater number of years of investment experience are likely to allocate a smaller proportion of their portfolio to a crowdfunding venture. This study shows that investment in crowdfunding ventures may not follow the norms of investment behavior and that supporters of crowdfunding are more focused on intrinsic motivations rather than extrinsic ones.

The remainder of the study is structured as follows: Section 2 discusses the theories surrounding the decision making process in a crowdfunding investment and this is followed by the proposed hypothetical model. The testable hypotheses are also presented in this section. Section 3 covers the data and methodology part, where sampling method and procedures and measurement of variables are discussed. Analysis of the data is carried out in Section 4 while the results are discussed in Section 5. The conclusion follows in Section 6.

\section{Literature Review and Hypothesis Development}

Entrepreneurship is one of the main drivers of economic growth but entrepreneurs face many obstacles in raising finance during the start-up phase of their business. This is due to various reasons such as limited business operating history and the riskiness of the business which may be because their ideas can be too innovative or complex to be understood. They therefore mostly rely on friends, family and fools [45] for their financing but this financing source is unfortunately insufficient to meet their needs. Studies by the Asian Development Bank reveal that around 9 million SMEs in Asia do not have sufficient access to formal financing and this lack of financing inhibits their growth. Only $18.7 \%$ of total bank lending in Asia are to SMEs while according to David Rose of Rose Tech Ventures [60], VCs typically invest in only 1 out of every 400 company they evaluate whilst angel investors have a higher hit rate of 1 in 40 companies. Entrepreneurs therefore need alternative sources of financing to realize the potentials of their ideas and crowdfunding is one of the emerging sources of alternative financing. Equity crowdfunding as an alternative financing mechanism has been growing in popularity over the years. Since crowdfunding relies on the crowd (the general public), its sustainability and growth depends on the motivations of the crowd to invest in the platforms.

Prior studies in psychology refer to the self-determination theory and the cognitive evaluation theory [25] in trying to explain the motivations for an individual's action. The self-determination theory focuses on the intrinsic and the extrinsic motivations and how they affect behavior [53]. Unlike extrinsic motivation, intrinsic motivation refers to internal motivations that are not associated with external rewards or pressures [19]. Hence an activity is considered to be intrinsically motivating if it contains elements that make it intrinsically interesting or if it is able to provide satisfaction of the basic psychological needs [53]. The cognitive evaluation theory extends the self-determination theory by focusing specifically on the three basic psychological needs (competence, autonomy and relatedness) that are satisfied in order for an individual to be intrinsically motivated [19]. Both competence and autonomy refer to the behavioral characteristics of self-efficacy [37] and self-determination [24], respectively, while relatedness refers to the perception and valuation of the behavior by others to whom the individual feels connected [12]. [19] extend these two theories in the context of crowdfunding and identify four key motivations for individual's willingness to participate in crowdfunding-collect rewards, be part of a community, help others and support a cause [33]. Out of the four, except for collect rewards which is considered to be an extrinsic motive, the other three are intrinsic motives.

Aside from the self-determination theory and the cognitive evaluation theory, another model used to explain decision making is the Cognitive-Affective paradigm by [30]. This paradigm builds on models and theories based on rational decision making such as the Rational Choice Theory [13] where the availability of information, the cognitive limitations of the mind and the time available to make a decision are the only restrictions present in the decisionmaking process [49]. The Cognitive-Affective paradigm incorporates the affective aspect of the decision-making process [31]. Where the cognitive process is rational, utilitarian and data-driven [31], the affective process is hedonic, feelings-driven and intuitive [49]. 
Based on the three theories, it is clear that the decision making process is a two-part process where individuals are motivated intrinsically and they make decisions based on the affective process; or they are extrinsically motivated and make decisions based on the cognitive process. The study considers the effect of the independent variables (intrinsic and extrinsic motivation) on the mediating variable (the decision to support) which in turn affects the dependent variable (proportion of portfolio likely to be invested in equity crowdfunding). The intrinsic motives considered in this study are trust, novelty, emotional value, aesthetic value and the desire to be part of a community while the extrinsic motive is the financial motive.

\subsection{Hypothesis Development}

Compared to other forms of crowdfunding, investors in equity crowdfunding ventures make an investment decision rather than a consumption decision. Hence, the financial motivation is expected to be the key driver for the investment in such a venture [19]. If supporters of equity crowdfunding ventures are similar to traditional investors, then their main aim would be to generate return from their investments. The rate of return on a supporter's investment is highly related to the future earnings of the company and its share value [49]. Traditional investment theory assumes investors are rational and make decisions based on the risk and return characteristics of the investment therefore these investors make cognitive evaluations of their investment and engage in certain behavior in order to obtain a certain desired outcome [53]. In terms of risk, since crowdfunding is not subject to the information disclosure requirements of traditional equity investments and it is an alternative source of funding, the risk is expected to be higher. Therefore, being rational investors, equity backers would be motivated to invest in crowdfunding ventures if the returns from their investments are high. The first hypothesis of this study is:

\section{H1: The financial value (return) of an equity crowdfunded venture has a significantly positive influence on the} decision to support the venture.

One of the key motivations for investors to pledge to a crowdfunding venture identified by [19] is the trust in the use of the funds. Trust refers to how comfortable investors feel about the use of the funds by the entrepreneurs [33]. Since entrepreneurs and SMEs use crowdfunding for raising funds and information asymmetry is very high in these ventures, trust is a very important factor. Information asymmetry is found to be greater in crowdfunding activities than in traditional financing method [2]. Funders have limited information and cognitive resources [63] in a crowdfunding environment, hence the ability to create trust and maintaining it improves the success rate of the projects [55]. Trustworthy sources of information provide quality information to investors and investors assess the projects based on information given during the campaign [42]. Comprehensive description of a project can enhance the success rate of funding raised [44] and trust can be built based on the high degree of informativeness provided by fundraisers [47]. Trust therefore plays an important value in the success of crowdfunding activities. The second hypothesis of this study is thus:

H2: Trust in the use of funds raised for an equity crowdfunded venture has a significantly positive influence on the decision to support the venture.

In consumer decision making, [56] identify epistemic value as a key factor in influencing decision. Epistemic value refers to the ability of a product "to arouse curiosity, provide novelty and/or satisfy the desire for knowledge" ([56], pp. 162). Therefore, providing something new or simply changing the pace or parts of the product can arouse the curiosity or the need for a difference within an individual. Novelty refers to the extent of the differentiation, valueadded and creativity of offerings compared to existing products [7]. Affective behavior from novelty can result in emotion-based behavior and this positive effect can influence action [10]. Creative projects can increase their competitive advantage among others [61], provide assurance of peak performance [23], but may result in failure if the projects are not creative [22]. According to [51], some individuals may be willing to pledge to support crowdfunded ventures in order to be able to pretest a novel product [19]. Supporters of equity crowdfunded ventures would therefore be willing to support the venture if their main reason for investing is to seek new experiences or to satisfy their curiosity given the newness of the concept despite the future prospects of the venture. Thus, the following hypothesis is formed.

H3: The ability of the crowdfunded venture to provide novel experiences and arouse curiosity regarding the venture has a significantly positive influence on the decision to support the venture.

In the context of crowdfunding, emotional desire for experiencing positive situations increases the chance for successful crowdfunding campaigns [41]. Loans and presales crowdfunding decisions are significantly found to be affected by emotional values [49] such as, having a feeling of satisfaction in taking part in building a business and enjoying the whole process of crowdfunding an investment. In charitable online platforms, the presence of rational and credible promotional campaigns increases the likelihood of receiving crowdfunds [48]. Accordingly, it is hypothesized that:

H4: The emotional value derived from supporting an equity crowdfunded venture has a significantly positive influence on the decision to support the venture. 
Since crowdfunding depends on the crowd, the crowdfunding process requires the support of the crowdfunding community. When the crowd funds projects, the consumer community will have the power to choose which company's product should be marketed or otherwise [17]. Crowdfunders will support business ideas within their community because they find it rewarding to help realize their local community's business ventures. Small investors are more sensitive to crowdfund based on a community's needs, as compared to professional investors who crowdfund following a market logic [3]. Crowdfunding processes that use the social media to finance innovative online projects, for instance, will have an incentive to gain support from the online community [17]. Individuals may pledge to equity crowdfunded ventures as it provides them with the perception of a shared identity [50]. Based on the arguments above,

H5: The feeling of belonging to a community as a result of supporting an equity crowdfunded venture has a significantly positive influence on the decision to support the venture.

Aesthetic quality is a question of beauty, appealing physical appearances, artistic or natural landscape [14]. Aesthetic values explain how a person reacts based on their experience of the surrounding of a beautiful or serene landscape, clean and tidy room, or even soothing sound of music. It has been proven that aesthetic values could be converted to social or economic advantages [46] that affect an individual's decisión to invest in crowdfunding projects According to [40], a project possesses aesthetic value if it is able to provoke positive feelings when experienced aesthetically hence crowdfund project developers have to strategically tailor their marketing communication plan [3] to attract individuals to fund an investment. On the contrary, [49] discovered that aesthetic values do not affect crowdfunding decisions. It is hypothesized that:

H6: The aesthetic value of an equity crowdfunded venture has a significantly positive influence on the decision to support the venture.

The willingness to support equity crowdfunding ventures reflects the intentions of the supporter to invest in the venture. According to the theory of Reasoned Action [6], [28], stronger intentions to perform a certain behavior leads to increased effort to perform the behavior and this increases the likelihood that the behavior will be performed. Hence, support of equity crowdfunding ventures is a behavioral intention (a function of attitudes and subjective norms) that has a significant positive effect on the likelihood of the actual investment in crowdfunding. Additionally, applying the Theory of Planned Behavior [4], [5] to this context, it is theoretically assumed that actual investments are made after the intention to invest is performed. However, [8] argue that based on the perceived behavioral control (PBC) by [5], under "circumstances where there were constraints on action, the mere formation of an intention was insufficient to predict behavior" ([8], pp. 472). Therefore, the relationship between willingness to support and the actual investment in crowdfunding may be insignificant. Assuming that the willingness to support results a higher likelihood to invest in an equity crowdfunding venture, the final hypothesis is:

H7: The willingness to support has a significant positive influence on the proportion of the portfolio an investor is likely to allocate for equity crowdfunding ventures.

Table 1 provides a summary of the relationships considered in this study, the expected signs and the corresponding theory/theories used to explain the relationships.

Table 1: Independent Variables, expected relationships and theories used

\begin{tabular}{|c|c|c|}
\hline Relationship & Expected Sign & Theory/Theories \\
\hline Financial value $\rightarrow$ decision to support & + & Cognitive Evaluation Theory \\
\hline Trust $\rightarrow$ decision to support & + & $\begin{array}{l}\text { Self-determination Theory \& Congitive } \\
\text { Evaluation Theory }\end{array}$ \\
\hline Novelty $\rightarrow$ decision to support & + & Cognitive-Affective Paradigm \\
\hline Emotional value $\rightarrow$ decision to support & + & Cognitive-Affective Paradigm \\
\hline Community $\rightarrow$ decision to support & + & $\begin{array}{l}\text { Self-determination Theory \& Congitive } \\
\text { Evaluation Theory }\end{array}$ \\
\hline Aesthetic Value $\rightarrow$ decision to support & + & Cognitive-Affective Paradigm \\
\hline $\begin{array}{l}\text { Willingness to support } \rightarrow \text { investment in } \\
\text { ECF }\end{array}$ & + & $\begin{array}{l}\text { Theory of Planned Behavior \& Theory of } \\
\text { Reasoned Action }\end{array}$ \\
\hline
\end{tabular}




\section{Data and Methodology}

In order to achieve the objectives of this study, primary data is collected via the use of survey questionnaires. The sampling method and data collection procedures are explained in this section. Further, the measurement of each variable (independent, dependent and control) is also discussed.

\subsection{Sampling Method and Procedures}

This study adopts the purposive (judgmental or subjective) sampling procedure, where only individuals who have prior knowledge of crowdfunding are considered in the sampling frame. To ensure this, a tracking question was included in the questionnaire, where the respondents were asked Do you know about crowdfunding?. Respondents had to answer Yes or No to this question. Only responses from respondents who answered Yes to this question were retained for the analysis in this study. All 6 equity crowdfunding platforms registered with the Securities Commission Malaysia were approached to assist with the distribution of the questionnaires to their investor clients. Out of the 6, three responded positively by agreeing to assist but finally only two of the platforms - PitchIN and CrowdPlus.asia - distributed the questionnaires to their investors via email. PitchIN is the first crowdfunding platform to be founded/launched in Malaysia and as of year 2018, is the leading equity crowdfunding operator in Malaysia. It had the highest percentage of the market share (75\%) of ECF deals in Malaysia in year 2018. Although CrowdPlus.asia was founded/launched a few years later, it is the first equity crowdfunding platform in the ASEAN región and is based in Malaysia.

Since PitchIN and CrowdPlus.asia preferred to email the questionnaire to their investors, a Google survey form was provided. A total of 26 responses ( 10 from PitchIN and 16 from CrowdPlus.asia) was obtained in this way. This total number of observations was however insufficient to carry out inferential analysis hence the researchers also approached individuals who were not necessarily investors in crowdfunding but had knowledge about crowdfunding and had considered investing in crowdfunded projects previously. A total of 46 responses was obtained in this way and this resulted in the total responses increasing to 72, which was still insufficient for the purpose of analysis. Using G-power, the minimum number of responses needed to carry out regression analysis with 7 independent variables given an effect size $f^{2}$ of 0.15 and alpha error probability of 0.05 is found to be 89 . To secure further responses, the researchers attended investor previews conducted by PitchIN, which were held almost every weekend (Saturdays and/or Sundays), and distributed the questionnaires manually to the participants. The responses were later keyed in manually. This approach resulted in 123 responses bringing the total to 195 responses. However, out of the 195 responses, a final sample of 169 responses were usable as some responses had missing data and some had invalid data where the respondents provided the same answers for all the statements, indicating disinterest in filling up the questionnaire. The final sample size of 169 is a more than adequate number to carry out the analysis.

\subsection{Measurement of Variables}

The dependent variable in this study is the proportion of his/her portfolio an investor is likely to allocate for equity crowdfunding ventures (Prop_Invest). This is asked using the question If you have invested or are interested in investing in a crowdfunding project, approximately what percentage of your investment portfolio have/would you allocate $(d)$ to this investment? Since respondents indicate the percentage amount, the dependent variable is a single item construct and an interval variable. The independent variables in this study represent the intrinsic and extrinsic motivations that could play a major role in the decision of an individual to support and invest in equity crowdfunding. Intrinsic motivations represent the nonfinancial motivations, in this case, trust of use of funds (Trust), be part of a community (Community) [19], desire for knowledge (Novelty), aesthetic appeal of the project/business (Aesthetic), and the emotional benefits derived from the project (Emotional) [49]. Extrinsic motivation, on the other hand, refers to the financial motivation, i.e. the financial returns that can be obtained from investing in the project/company (Financial). The mediating variable is the willingness to support a project/company that is crowdfunded (Support). For both the independent and mediating variables, a five-point Likert scale is used as the response format, with values ranging from 1 being Strongly Disagree to 5 being Strongly Agree, to gauge the level of agreement/disagreement of the respondents to the statements that measure each construct. Finally, a control variable previous investment experience (Prev_experience) is also included to control for differences in the respondents' investment experience that might influence the proportion invested in the project. This variable is a single item construct and is of an interval scale where respondents provide a number for the total years of experience they have had in the investment field. [39] find that the learning-by-doing phenomenon through experience is present in equity crowdfunding investments; i.e. as investors become more familiar with the investments, they are less prone to bias. However, their previous investment experience may not be in crowdfunding ventures hence this variable may or may not be significant in influencing the proportion invested in the venture.

The items for each construct/variable are provided in Table 2 along with the sources from which these questions were adopted. 
Table 2: Items for construct/variable and their source

\begin{tabular}{|c|c|c|c|}
\hline Construct/Variable & Item Name & Item & Source \\
\hline \multicolumn{4}{|c|}{ DEPENDENT VARIABLE } \\
\hline $\begin{array}{l}\text { Proportion } \\
\text { Investment Portfolio }\end{array}$ & Prop_Invest & $\begin{array}{l}\text { If you have invested or are interested in } \\
\text { investing in a crowdfunding project, } \\
\text { approximately what percentage of your } \\
\text { investment portfolio have/would you allocate(d) } \\
\text { to this investment? }\end{array}$ & $\begin{array}{l}\text { Authors' } \\
\text { own }\end{array}$ \\
\hline \multicolumn{4}{|c|}{ INDEPENDENT VARIABLES } \\
\hline \multirow{3}{*}{ Financial } & FIN1 & $\begin{array}{l}\text { I expect to gain good monetary return if this } \\
\text { project succeeds. }\end{array}$ & [49] \\
\hline & FIN2 & $\begin{array}{l}\text { I may win big money with small money if I } \\
\text { support this project. }\end{array}$ & [49] \\
\hline & FIN3 & $\begin{array}{l}\text { My primary goal is to generate return on my } \\
\text { investment. }\end{array}$ & [19] \\
\hline \multirow{3}{*}{ Trust } & TRU1 & $\begin{array}{l}\text { I want to feel sure that the team knows how to } \\
\text { handle the funds they raise for the project. }\end{array}$ & [19] \\
\hline & TRU2 & $\begin{array}{l}\text { It is important that the team knows how long it } \\
\text { takes from raising the funds to production and } \\
\text { shipping. }\end{array}$ & [19] \\
\hline & TRU3 & $\begin{array}{l}\text { I invest if I feel confident that my money will be } \\
\text { used wisely by the founders. }\end{array}$ & [19] \\
\hline \multirow{3}{*}{ Novelty } & NOV1 & $\begin{array}{l}\text { Supporting the project would satisfy my sense of } \\
\text { curiosity. }\end{array}$ & [49] \\
\hline & NOV2 & $\begin{array}{l}\text { Supporting the project would offer novel } \\
\text { experiences. }\end{array}$ & [49] \\
\hline & NOV3 & $\begin{array}{l}\text { If I supported the project I would feel like I'm } \\
\text { exploring new worlds. }\end{array}$ & [49] \\
\hline \multirow{4}{*}{ Emotional } & EMO1 & $\begin{array}{l}\text { Supporting the project would arouse positive } \\
\text { feelings in me. }\end{array}$ & [49] \\
\hline & EMO2 & I would have fun supporting the project. & [49] \\
\hline & EMO3 & $\begin{array}{l}\text { The actual process of supporting the project } \\
\text { would give me pleasure. }\end{array}$ & [49] \\
\hline & EMO4 & $\begin{array}{l}\text { I invest in investment projects for the pure } \\
\text { enjoyment of it. }\end{array}$ & [36] \\
\hline \multirow{3}{*}{ Community } & COM1 & $\begin{array}{l}\text { I enjoy the feeling of belonging to a community } \\
\text { of other backers. }\end{array}$ & [19] \\
\hline & COM2 & $\begin{array}{l}\text { I find it gratifying to see myself on the list of } \\
\text { supporters for a project. }\end{array}$ & [19] \\
\hline & COM3 & $\begin{array}{l}\text { I like to interact with the online community of } \\
\text { backers and offer my advice about the project. }\end{array}$ & [19] \\
\hline \multirow{3}{*}{ Aesthetic } & AES1 & The way the project is displayed is attractive. & [49] \\
\hline & AES2 & The project's page is aesthetically appealing. & [49] \\
\hline & AES3 & I like the way the project looks. & [49] \\
\hline \multicolumn{4}{|l|}{ MEDIATING VARIABLE } \\
\hline \multirow{3}{*}{ Support } & SUP1 & $\begin{array}{l}\text { I want to support ideas that promise to have } \\
\text { social impact. }\end{array}$ & [19] \\
\hline & SUP2 & $\begin{array}{l}\text { I like to back good ideas and give founders the } \\
\text { opportunity to retain control of their ventures. }\end{array}$ & [19] \\
\hline & SUP3 & $\begin{array}{l}\text { I enjoy the collaborative spirit in such } \\
\text { investments and I want to help people realize } \\
\text { their ideas. }\end{array}$ & [19] \\
\hline \multicolumn{4}{|l|}{ CONTROL VARIABLE } \\
\hline $\begin{array}{l}\text { Previous Investment } \\
\text { Experience }\end{array}$ & Prev_experience & $\begin{array}{l}\text { How many years of investment experience do } \\
\text { you have? }\end{array}$ & $\begin{array}{l}\text { Authors' } \\
\text { own }\end{array}$ \\
\hline
\end{tabular}

\section{Analysis of Data}

Having collected the data and ensuring the reliability and the validity of the data, various statistical analyses are then carried out on the data to ensure the reliability and the validity of the data, to gain an understanding of the respondents in this study and to explore the various motivations that could influence these respondents' willingness to invest in equity crowdfunding projects. 


\subsection{Preliminary Univariate Analysis}

Frequency analysis is first carried out based on the demographic category of the respondents to understand the characteristics of the sample. Additionally, for each demographic category, non-parametric analysis is carried out for the groups to evaluate if there is any difference in mean Prop_Invest. For demographic types with two groups, Mann-Whitney $U$ test is performed while for those with more than two groups, Kruskal-Wallis $\mathrm{H}$ test is performed. Results of the frequency analysis and analysis of differences in means are presented in Table 3.

Table 3: Frequency Analysis

\begin{tabular}{|c|c|c|c|c|c|}
\hline Demographic Type & Group & Frequency & Percent & $\begin{array}{l}\text { Porp_Invest } \\
\text { Mean Rank }\end{array}$ & p-value \\
\hline \multirow{4}{*}{ Age } & 20 or younger & 2 & 1.2 & 9.25 & \multirow{4}{*}{0.004} \\
\hline & 21 to 40 & 112 & 66.3 & 88.72 & \\
\hline & 41 to 60 & 50 & 29.6 & 85.15 & \\
\hline & 61 and older & 5 & 3.0 & 30.40 & \\
\hline \multirow{2}{*}{ Gender } & Female & 65 & 38.5 & 88.59 & \multirow{2}{*}{0.424} \\
\hline & Male & 104 & 61.5 & 82.75 & \\
\hline \multirow{4}{*}{ Race } & Chinese & 61 & 36.1 & 89.59 & \multirow{4}{*}{0.594} \\
\hline & Indian & 34 & 20.1 & 88.78 & \\
\hline & Malay & 66 & 39.1 & 80.08 & \\
\hline & Others & 8 & 4.70 & 75.75 & \\
\hline \multirow{5}{*}{ Occupation } & Employee & 79 & 46.7 & 80.61 & \multirow{5}{*}{0.119} \\
\hline & Retiree & 1 & 0.6 & 16.00 & \\
\hline & Self-Employed & 83 & 49.1 & 89.60 & \\
\hline & Student & 5 & 3.0 & 74.90 & \\
\hline & Unemployed & 1 & 0.6 & 169.00 & \\
\hline \multirow{5}{*}{ Education } & $\begin{array}{l}\text { High School / } \\
\text { Certificate }\end{array}$ & 6 & 3.6 & 27.7 & \multirow{5}{*}{0.008} \\
\hline & Diploma & 30 & 17.8 & 96.73 & \\
\hline & Bachelor Degree & 95 & 56.2 & 84.21 & \\
\hline & Master Degree & 31 & 18.3 & 84.79 & \\
\hline & $\mathrm{PhD}$ & 7 & 4.1 & 95.57 & \\
\hline \multirow{2}{*}{$\begin{array}{l}\text { Professional } \\
\text { Certification }\end{array}$} & No & 150 & 88.8 & 86.30 & \multirow{2}{*}{0.302} \\
\hline & Yes & 19 & 11.2 & 74.71 & \\
\hline \multirow{2}{*}{$\begin{array}{l}\text { Prior Investment } \\
\text { Experience }\end{array}$} & No & 11 & 6.5 & 30.50 & \multirow{2}{*}{0.000} \\
\hline & Yes & 158 & 93.5 & 88.79 & \\
\hline \multirow{2}{*}{$\begin{array}{l}\text { Invested in } \\
\text { Crowdfunding before }\end{array}$} & No & 86 & 50.9 & 79.09 & \multirow{2}{*}{0.090} \\
\hline & Yes & 83 & 49.1 & 91.13 & \\
\hline
\end{tabular}

Based on the demographic profile, majority of the respondents are between the ages of 21 to $40(66.23 \%)$, i.e. most of those interested in equity crowdfunding are millennials or the Gen $\mathrm{Y}$. This confirms various reports such as by [11], [57] that mostly millennials are more involved with ECF. The respondents are mostly males (61.5\%) [38] and of the ethnic-Malay (39.1\%) and Chinese (36.1\%) race. They are either self-employed (49.1\%) or employees $(46.7 \%)$ while the rest are either students, retirees or unemployed. More than half of the respondents $(56.2 \%)$ have Bachelor degrees, with Diploma holders and Master degree holders each making up around $18 \%$ of the total respondents. Only very few of the respondents (11.2\%) have a professional certificate. Out of the 169 respondents, only 11 $(6.5 \%)$ do not have any previous investment experience while $158(93.5 \%)$ do. Finally, the sample is made up of almost equal numbers of those with $(49.1 \%)$ and without $(50.9 \%)$ previous experience in crowdfunding. Analysis of differences in mean (in Table 3) shows significant differences in the proportion of his/her portfolio an investor is likely to allocate to crowdfunding ventures (Prop_Invest) based on age, education level, prior investment experience and whether or not they have invested in a crowdfunding venture (although this is only at the $10 \%$ level). No significant difference is found in the mean based on gender, race, occupation and professional certification. As an additional analysis (not provided in the table), it is found that more than half (117 out of 169) have or would allocate more than $10 \%$ of their portfolio to crowdfunding ventures.

\subsection{Exploratory Factor Analysis and Reliability Analysis}

Since the measurements for each of the independent and mediating variables are adopted from different sources, exploratory factor analysis is first carried out in the first phase of the pilot test so that multicollinearity among the indicators in the measurement model can be reduced [1]. Principal component analysis is carried out on the 22 items using orthogonal rotation (varimax). Descriptive statistics of all the indicators and the dependent variable Prop_Invest, the correlations between indicators and the pattern matrix are provided in Tables 4 and 5 respectively. 
Table 4: Descriptive Statistics

\begin{tabular}{|l|l|l|}
\hline & Mean & Std. Deviation \\
\hline FIN1 & 4.21 & 0.796 \\
\hline FIN2 & 3.86 & 0.919 \\
\hline FIN3 & 4.09 & 0.956 \\
\hline TRU1 & 3.89 & 0.869 \\
\hline TRU2 & 3.99 & 0.838 \\
\hline TRU3 & 3.93 & 0.939 \\
\hline NOV1 & 3.49 & 0.977 \\
\hline NOV2 & 3.59 & 0.876 \\
\hline NOV3 & 3.63 & 0.998 \\
\hline EMO1 & 3.53 & 1.058 \\
\hline EMO2 & 3.47 & 0.994 \\
\hline EMO3 & 3.46 & 1.041 \\
\hline EMO4 & 3.29 & 1.152 \\
\hline COM1 & 3.36 & 1.044 \\
\hline COM2 & 3.35 & 1.076 \\
\hline COM3 & 3.44 & 0.993 \\
\hline AES1 & 3.79 & 0.958 \\
\hline AES2 & 3.82 & 0.924 \\
\hline AES3 & 3.79 & 0.865 \\
\hline SUP1 & 3.59 & 1.009 \\
\hline SUP2 & 3.79 & 0.899 \\
\hline SUP3 & 3.70 & 0.898 \\
\hline Prop_Invest & 0.122 & 0.107 \\
\hline
\end{tabular}

Descriptive statistics in Table 4 show all indicators have mean values of above 3.20 , indicating that on average the respondents agreed with the statements. On average, the respondents indicated that they have or would invest around $12 \%$ of their portfolio in a crowdfunding project/business.

Table 5: Pattern Matrix

\begin{tabular}{|c|c|c|c|c|c|c|c|c|c|c|}
\hline \multirow[t]{2}{*}{ Factors } & & \multicolumn{7}{|c|}{ Component } & \multirow{2}{*}{$\begin{array}{l}\mathrm{KMO} \text { and } \\
\text { Bartlett's test }\end{array}$} & \multirow{2}{*}{$\begin{array}{l}\text { Cronbach' } \\
\text { s a }\end{array}$} \\
\hline & & 1 & 2 & 3 & 4 & 5 & 6 & 7 & & \\
\hline \multirow{3}{*}{ Financial } & FIN1 & & & & & & & 0.746 & \multirow{3}{*}{0.663} & \multirow{3}{*}{0.700} \\
\hline & FIN2 & & & & & & & 0.801 & & \\
\hline & FIN3 & & & & & & & 0.766 & & \\
\hline \multirow{3}{*}{ Trust } & TRU1 & & & & 0.784 & & & & \multirow{3}{*}{0.693} & \multirow{3}{*}{0.776} \\
\hline & TRU2 & & & & 0.915 & & & & & \\
\hline & TRU3 & & & & 0.752 & & & & & \\
\hline \multirow{3}{*}{ Novelty } & NOV1 & & 0.877 & & & & & & \multirow{3}{*}{0.726} & \multirow{3}{*}{0.858} \\
\hline & NOV2 & & 0.842 & & & & & & & \\
\hline & NOV3 & & 0.842 & & & & & & & \\
\hline \multirow{4}{*}{ Emotional } & EMO1 & 0.700 & & & & & & & \multirow{4}{*}{0.804} & \multirow{4}{*}{0.865} \\
\hline & EMO2 & 0.823 & & & & & & & & \\
\hline & EMO3 & 0.825 & & & & & & & & \\
\hline & EMO4 & 0.812 & & & & & & & & \\
\hline \multirow{3}{*}{ Community } & COM1 & & & 0.787 & & & & & \multirow{3}{*}{0.742} & \multirow{3}{*}{0.886} \\
\hline & COM2 & & & 0.862 & & & & & & \\
\hline & COM3 & & & 0.882 & & & & & & \\
\hline \multirow{3}{*}{ Aesthetic } & AES1 & & & & & & 0.676 & & \multirow{3}{*}{0.712} & \multirow{3}{*}{0.820} \\
\hline & AES2 & & & & & & 0.791 & & & \\
\hline & AES3 & & & & & & 0.749 & & & \\
\hline \multirow{3}{*}{ Support } & SUP1 & & & & & 0.660 & & & \multirow{3}{*}{0.701} & \multirow{3}{*}{0.799} \\
\hline & SUP2 & & & & & 0.643 & & & & \\
\hline & SUP3 & & & & & 0.760 & & & & \\
\hline
\end{tabular}

The factor analysis in Table 5 shows 7 distinct factors corresponding to (1) Emotional, (2) Novelty, (3) Community, (4) Trust, (5) Support, (6) Aesthetic and (7) Financial with all factor loadings being above 0.6 and communalities of all variables are found to be greater than 0.6 [59]. Kaiser-Meyer-Olkin (KMO) measure of sampling adequacy is found to be 0.879 for all factors while the p-value for Bartlett's test of sphericity is 0.000 . KMO value for each variable is found to be above the acceptable level of 0.5 [27]. Reliability analysis is carried out using Cronbach's Alpha which is found to be greater than 0.7 [35] for each variable with values ranging from 0.7 to 0.886 , indicating 
adequate to good internal consistency of the indicators. The result of the EFA, test of sampling adequacy and test of internal consistency confirm the appropriateness of the items in measuring the independent and mediating variables.

The Harman's single-factor test is carried out to test for the presence of common method variance in the dataset as the data was obtained from a single source, i.e. the investors. All variables are loaded onto a single factor and the constraint of no rotation is imposed as recommended by [52]. The total variance explained by the single factor is less than $50 \%$, i.e. $36.642 \%$ indicating the absence of the common method variance problem.

\subsection{Further Univariate Analysis}

Having identified the measurements for each variable, a means difference analysis is carried out on each variable to analyze if there are any significant difference in each construct based on the different demographic categories indicated in Table 3 earlier. The average score of each variable is calculated for each respondent. Again, MannWhitney $\mathrm{U}$ test or Kruskal-Wallis $\mathrm{H}$ tests are performed depending on the number of groups under each demographic category. The results of the means difference analysis are provided in Table 6.

Table 6: Analysis of Mean Differences

\begin{tabular}{|c|c|c|c|c|c|c|c|c|}
\hline Age & $\mathbf{N}$ & SUPPORT & FINANCIAL & TRUST & NOVELTY & EMOTIONAL & COMMUNITY & AESTHETIC \\
\hline $\begin{array}{l}20 \text { or } \\
\text { younger }\end{array}$ & 2 & 67.50 & 71.00 & 73.25 & 13.50 & 47.50 & 13.50 & 53.00 \\
\hline 21 to 40 & 112 & 85.43 & 87.84 & 83.18 & 87.72 & 86.67 & 89.81 & 84.80 \\
\hline 41 to 60 & 50 & 85.88 & 79.65 & 89.24 & 83.43 & 85.83 & 81.46 & 86.03 \\
\hline \multirow[t]{2}{*}{60 or older } & 5 & 73.50 & 80.40 & 88.00 & 68.40 & 54.20 & 41.30 & 91.90 \\
\hline & p-value & 0.903 & 0.750 & 0.878 & 0.149 & 0.343 & 0.021 & 0.799 \\
\hline Gender & $\mathbf{N}$ & SUPPORT & FINANCIAL & TRUST & NOVELTY & EMOTIONAL & COMMUNITY & AESTHETIC \\
\hline Male & 104 & 79.69 & 85.12 & 83.03 & 82.85 & 77.44 & 76.15 & 80.58 \\
\hline \multirow[t]{2}{*}{ Female } & 65 & 93.50 & 84.82 & 88.15 & 88.44 & 97.10 & 99.15 & 92.08 \\
\hline & $p$-value & 0.071 & 0.969 & 0.504 & 0.466 & 0.011 & 0.003 & 0.131 \\
\hline Race & $\mathbf{N}$ & SUPPORT & FINANCIAL & TRUST & NOVELTY & \multicolumn{2}{|c|}{ EMOTIONAL COMMUNITY } & AESTHETIC \\
\hline Malay & 66 & 87.98 & 78.36 & 88.55 & 88.50 & 90.33 & 88.45 & 91.20 \\
\hline Chinese & 61 & 82.97 & 89.45 & 74.26 & 85.60 & 82.84 & 78.91 & 86.12 \\
\hline Indian & 34 & 85.66 & 89.96 & 96.25 & 78.49 & 79.04 & 83.40 & 78.29 \\
\hline \multirow[t]{2}{*}{ Others } & 8 & 73.06 & 84.81 & 89.81 & 79.25 & 82.81 & 109.75 & 53.75 \\
\hline & $p$-value & 0.837 & 0.548 & 0.152 & 0.782 & 0.698 & 0.332 & 0.161 \\
\hline Occupation & $\mathbf{N}$ & SUPPORT & FINANCIAL & TRUST & NOVELTY & \multicolumn{2}{|c|}{ EMOTIONAL COMMUNITY } & AESTHETIC \\
\hline Student & 5 & 85.30 & 37.00 & 69.80 & 76.70 & 76.10 & 90.30 & 91.40 \\
\hline Employee & 79 & 87.14 & 91.58 & 86.09 & 85.73 & 81.85 & 86.24 & 90.30 \\
\hline $\begin{array}{l}\text { Self- } \\
\text { Employed }\end{array}$ & 83 & 81.40 & 81.46 & 83.98 & 83.78 & 88.37 & 84.02 & 78.84 \\
\hline Unemployed & 1 & 164.00 & 77.00 & 156.50 & 140.00 & 81.50 & 77.50 & 130.00 \\
\hline \multirow[t]{2}{*}{ Retiree } & 1 & 134.50 & 106.50 & 88.50 & 115.50 & 102.00 & 49.00 & 101.00 \\
\hline & p-value & 0.364 & 0.133 & 0.599 & 0.754 & 0.907 & 0.949 & 0.496 \\
\hline Education & $\mathbf{N}$ & SUPPORT & FINANCIAL & TRUST & NOVELTY & \multicolumn{2}{|c|}{ EMOTIONAL COMMUNITY } & AESTHETIC \\
\hline $\begin{array}{l}\text { High } \\
\text { School / } \\
\text { Certificate }\end{array}$ & 6 & 76.50 & 84.33 & 104.42 & 93.08 & 64.83 & 64.75 & 109.58 \\
\hline Diploma & 30 & 95.10 & 76.33 & 83.13 & 87.23 & 92.65 & 82.43 & 77.10 \\
\hline $\begin{array}{l}\text { Bachelor } \\
\text { Degree }\end{array}$ & 95 & 81.95 & 88.55 & 81.29 & 84.17 & 87.11 & 88.28 & 81.44 \\
\hline $\begin{array}{l}\text { Master } \\
\text { Degree }\end{array}$ & 31 & 83.74 & 85.37 & 93.71 & 81.26 & 72.92 & 75.55 & 96.74 \\
\hline \multirow[t]{2}{*}{ PhD } & 7 & 95.93 & 72.93 & 88.14 & 96.29 & 94.43 & 110.64 & 94.14 \\
\hline & p-value & 0.691 & 0.752 & 0.626 & 0.936 & 0.390 & 0.320 & 0.289 \\
\hline
\end{tabular}




\begin{tabular}{|c|c|c|c|c|c|c|c|c|}
\hline \multicolumn{9}{|c|}{ Table 6: continuation } \\
\hline $\begin{array}{l}\text { Professional } \\
\text { Certification }\end{array}$ & $\mathbf{N}$ & SUPPORT & FINANCIAL & TRUST & NOVELTY & EMOTIONAL & COMMUNITY & AESTHETIC \\
\hline No & 150 & 83.55 & 85.67 & 83.76 & 85.95 & 85.81 & 86.27 & 83.92 \\
\hline \multirow[t]{2}{*}{ Yes } & 19 & 96.45 & 79.71 & 94.79 & 77.53 & 78.61 & 74.95 & 93.50 \\
\hline & $p$-value & 0.274 & 0.613 & 0.349 & 0.476 & 0.543 & 0.338 & 0.414 \\
\hline $\begin{array}{l}\text { Prior } \\
\text { Investment } \\
\text { Experience }\end{array}$ & $\mathbf{N}$ & SUPPORT & FINANCIAL & TRUST & NOVELTY & EMOTIONAL & COMMUNITY & AESTHETIC \\
\hline No & 11 & 101.68 & 60.55 & 83.23 & 93.77 & 87.36 & 68.64 & 113.73 \\
\hline \multirow[t]{2}{*}{ Yes } & 158 & 83.84 & 86.70 & 85.12 & 84.39 & 84.84 & 86.14 & 83.00 \\
\hline & $p$-value & 0.237 & 0.083 & 0.900 & 0.535 & 0.868 & 0.247 & 0.041 \\
\hline $\begin{array}{l}\text { Invested in } \\
\text { Crowdfund } \\
\text { ing Before }\end{array}$ & $\mathbf{N}$ & SUPPORT & FINANCIAL & TRUST & NOVELTY & EMOTIONAL & COMMUNITY & AESTHETIC \\
\hline No & 86 & 89.70 & 87.31 & 88.20 & 87.99 & 89.06 & 91.83 & 91.16 \\
\hline Yes & 83 & 80.13 & 82.60 & 81.69 & 81.90 & 80.80 & 77.93 & 78.62 \\
\hline & $p$-value & 0.198 & 0.527 & 0.382 & 0.414 & 0.270 & 0.063 & 0.091 \\
\hline
\end{tabular}

The analyses of mean for the demographic categories of Race, Occupation, Education and Professional Certification show that there is no significant difference in the mean among the groups in each category for each variable. For the category of Age, significant difference is found for the variable Community, where those in the age group of 2140 assign significantly higher values to the statements relating to being part of a community compared to those in the other age groups. Significant differences are also found for the category of Gender, whereby females assign significantly higher values to the variables Support, Emotional and Community. This implies that females are more likely to support a crowdfunding venture and they may be more likely to be emotionally or socially (Community) motivated compared to males. Those with previous investment experience have higher financial motivations compared to those who do not have any experience but the ones with no previous investment experience assign significantly greater importance to Aesthetic. It is also found that the need to be part of a community and the aesthetic appeal of the project/business is higher for those who have not invested in crowdfunding before, although the difference is only significant at the $10 \%$ level.

\subsection{Structural Model}

The relationship between the dependent, mediating and independent variables is analyzed via SEM-PLS. The overall model is presented in Figure 1. All the variables are treated as reflective measurement models as the latent constructs exist independent of the measures used with variations in the constructs causing variations in the item measurements.

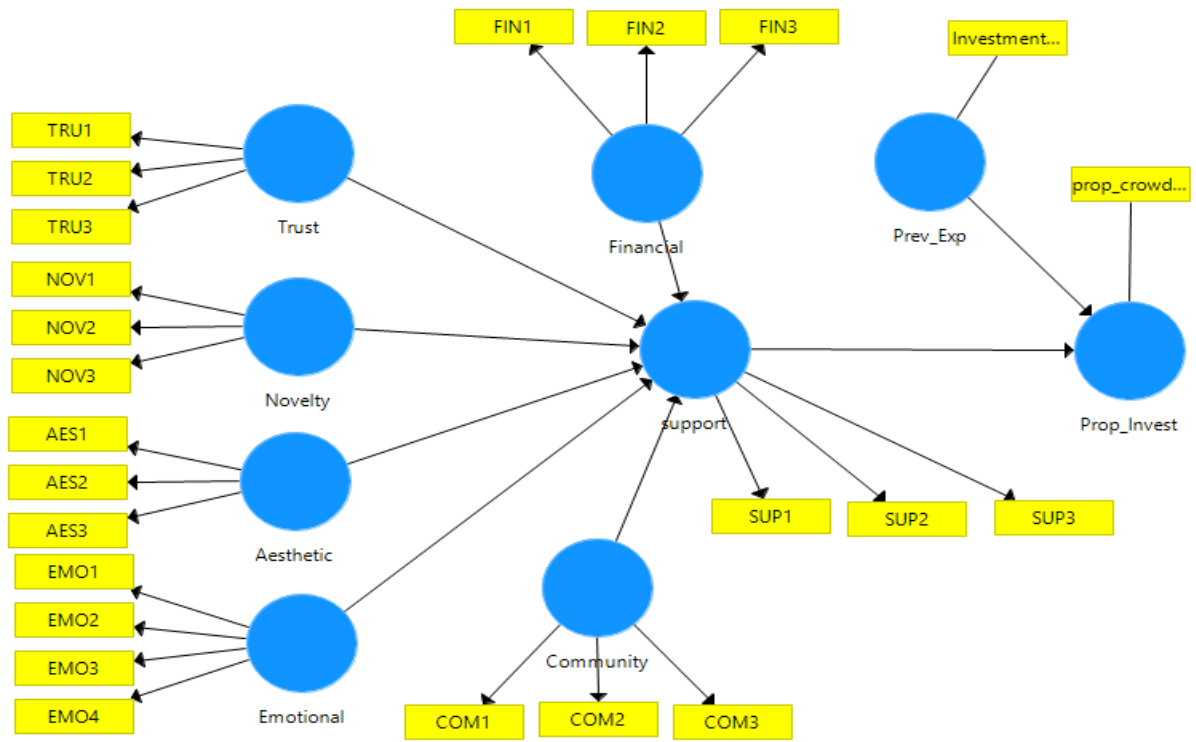

Figure 1: Structural Model of the motivations to invest in equity crowdfunding 
Assessment of the reflective measurement models is first carried out before the measurement model is evaluated. Internal consistency, indicator reliability, convergent validity and discriminant validity are first assessed. Additionally, outer loadings for all the indicators are calculated. Internal consistency is measured via the Cronbach's alpha and as per the values obtained from the factor analysis, the values for all constructs range between 0.7 and 0.886 satisfying the internal consistency requirement. Composite reliability is found to be greater than 0.8 for all indicators indicating sufficient convergence or internal consistency [32]. Average Variance Extracted (AVE) values also indicate adequate convergent validity with values greater than 0.5 for all constructs. The outer loading is found to be greater than 0.6 for all indicators hence fulfilling the indicator reliability condition. Discriminant validity is assessed via the HeterotraitMonotrait Ration (HTMT) and the Fornell-Larcker Criterion [29] and the results show that this condition is also satisfied. Finally, collinearity statistics (VIF) are calculated for all the constructs and the highest inner VIF value is found to be 2.084 (for Community) while the highest outer VIF value is 2.744 (for COM2). Since all values are found to be less than 3 , no collinearity issues are detected between the constructs and the indicators. A summary of the results of the various assessments is provided in Table 7.

Table 7: Summary of Measurement Models

\begin{tabular}{|c|c|c|c|c|c|c|c|}
\hline Construct & Indicator & $\begin{array}{l}\text { Outer } \\
\text { loading }\end{array}$ & $\begin{array}{l}\text { Cronbach's } \\
\text { Alpha }\end{array}$ & $\begin{array}{l}\text { Composite } \\
\text { reliability }\end{array}$ & AVE & $\begin{array}{l}\text { Discriminant } \\
\text { validity }\end{array}$ & VIF \\
\hline \multirow{3}{*}{ Financial } & FIN1 & 0.856 & \multirow{3}{*}{0.695} & \multirow{3}{*}{0.815} & \multirow{3}{*}{0.597} & \multirow{3}{*}{ Yes } & 1.308 \\
\hline & FIN2 & 0.768 & & & & & 1.348 \\
\hline & FIN3 & 0.685 & & & & & 1.285 \\
\hline \multirow{3}{*}{ Trust } & TRU1 & 0.887 & \multirow{3}{*}{0.778} & \multirow{3}{*}{0.870} & \multirow{3}{*}{0.690} & \multirow{3}{*}{ Yes } & 1.765 \\
\hline & TRU2 & 0.799 & & & & & 1.618 \\
\hline & TRU3 & 0.804 & & & & & 1.510 \\
\hline \multirow{3}{*}{ Novelty } & NOV1 & 0.894 & \multirow{3}{*}{0.859} & \multirow{3}{*}{0.914} & \multirow{3}{*}{0.780} & \multirow{3}{*}{ Yes } & 2.365 \\
\hline & NOV2 & 0.845 & & & & & 1.907 \\
\hline & NOV3 & 0.909 & & & & & 2.409 \\
\hline \multirow{4}{*}{ Emotional } & EMO1 & 0.874 & \multirow{4}{*}{0.868} & \multirow{4}{*}{0.910} & \multirow{4}{*}{0.718} & \multirow{4}{*}{ Yes } & 2.438 \\
\hline & EMO2 & 0.865 & & & & & 2.312 \\
\hline & EMO3 & 0.900 & & & & & 2.719 \\
\hline & EMO4 & 0.741 & & & & & 1.704 \\
\hline \multirow{3}{*}{ Community } & COM1 & 0.900 & \multirow{3}{*}{0.886} & \multirow{3}{*}{0.929} & \multirow{3}{*}{0.814} & \multirow{3}{*}{ Yes } & 2.738 \\
\hline & COM2 & 0.917 & & & & & 2.744 \\
\hline & COM3 & 0.889 & & & & & 2.258 \\
\hline \multirow{3}{*}{ Aesthetic } & AES1 & 0.861 & \multirow{3}{*}{0.821} & \multirow{3}{*}{0.893} & \multirow{3}{*}{0.736} & \multirow{3}{*}{ Yes } & 1.831 \\
\hline & AES2 & 0.873 & & & & & 2.032 \\
\hline & AES3 & 0.840 & & & & & 1.733 \\
\hline \multirow{3}{*}{ Support } & SUP1 & 0.887 & \multirow{3}{*}{0.802} & \multirow{3}{*}{0.883} & & & 1.548 \\
\hline & SUP2 & 0.799 & & & 0.716 & Yes & 1.883 \\
\hline & SUP3 & 0.804 & & & & & 1.872 \\
\hline Prev_experience & & 1.000 & 1.000 & 1.000 & 1.000 & Yes & 1.000 \\
\hline Prof_Invest & & 1.000 & 1.000 & 1.000 & 1.000 & Yes & 1.000 \\
\hline
\end{tabular}

A summary of the relationships, their significance and the model fit statistics of the structural model are provided in Table 8. The independent variables (Financial, Trust, Novelty, Emotional, Community and Aesthetic) are found to explain 56.5\% of the variation in Support while Support and Prev_experience are able to explain only 6\% of the variation in Prop invest. Model fit statistics show good model fit with SRMR being 0.064 (less than 0.08 as proposed by [43]). Using blindfolding procedure (with omission distance of $D=7$ ) shows predictive relevance $\left(Q^{2}\right)$ for Support to be 0.336 while the value for Prop_invest is 0.035 . 
Table 8: Summary of Structural Model

\begin{tabular}{|c|c|c|c|c|}
\hline Direct Effects & Path Coefficient & $f^{2}$ & $\mathbf{R}^{2}$ & SRMR \\
\hline Financial -> Support & 0.069 & 0.010 & \multirow{6}{*}{0.565} & \multirow{15}{*}{0.064} \\
\hline Trust -> Support & $0.195^{\star \star \star}$ & 0.069 & & \\
\hline Novelty -> Support & $0.207^{* * *}$ & 0.052 & & \\
\hline Emotional -> Support & $0.204^{* *}$ & 0.047 & & \\
\hline Community -> Support & 0.045 & 0.002 & & \\
\hline Aesthetic -> Support & $0.330^{\star * \star}$ & 0.156 & & \\
\hline Support -> Prop_Invest & $0.202^{* *}$ & 0.043 & \multirow{2}{*}{0.060} & \\
\hline Prev_exp -> Prop_Invest & $-0.126^{\star \star}$ & 0.017 & & \\
\hline \multicolumn{4}{|l|}{ Indirect Effects } & \\
\hline Financial -> Prop_Invest & 0.014 & & & \\
\hline Trust -> Prop_Invest & $0.039^{* *}$ & & & \\
\hline Novelty -> Prop_Invest & $0.042^{*}$ & & & \\
\hline Emotional -> Prop_Invest & 0.041 & & & \\
\hline Community -> Prop_Invest & 0.009 & & & \\
\hline Aesthetic -> Prop_Invest & $0.067^{* \star}$ & & & \\
\hline
\end{tabular}

Using bootstrap method with 500 subsample setting, the path coefficient between Support and Prop invest is found to be highly significant at $5 \%$ level. Referring to the direct effect, all the variables representing the different motivations are found to be significant in influencing the willingness to support a crowdfunded venture at least at the $5 \%$ level, except for Community and Financial, which are insignificant. The $\mathrm{f}^{2}$ effect size is found to be small (less than 0.1) for all the relationships except between Aesthetic and Support which has an $\mathrm{f}^{2}$ of 0.156 (moderate effect). The indirect effect shows that only Trust and Aesthetic have significant influences on Prop_Invest while Novelty is only significant at the $10 \%$ level. The control variable, Prev_experience is found to have a significant negative relationship with Prop_invest although the $\mathrm{f}^{2}$ value is only 0.017 , indicating small effect size.

\subsection{PLS Multi-Group Analysis (PLS-MGA)}

Finally, as a robustness check, PLS Multi-Group Analysis (PLS-MGA) is carried out because the respondents are from two different groups, i.e. those who have invested in equity crowdfunding projects before (83 respondents) and those who have not but intend to invest in the future (86 respondents). The PLS-MGA analysis allows to test for significant differences in the group-specific parameter estimates of the two groups of respondents. The results presented in Table 9 show that aside from the relationship between Prev_experience and Prop_Invest ( $p$-value of the difference in the path coefficient is 0.011 ), there is no significant difference in the path coefficients for the two groups of respondents ( $p$-values of the difference in the path coefficients are greater than 0.05). Therefore, it is evident that there is no significant difference in the motivations to support equity crowdfunding between the two groups of respondents.

Table 9: PLS-MGA results

\begin{tabular}{|l|l|l|}
\hline Direct Effects & Path Coefficient-difference & p-value \\
\hline Financial -> Support & 0.099 & 0.758 \\
\hline Trust -> Support & 0.007 & 0.519 \\
\hline Novelty -> Support & 0.145 & 0.195 \\
\hline Emotional -> Support & 0.107 & 0.270 \\
\hline Community -> Support & 0.127 & 0.790 \\
\hline Aesthetic -> Support & 0.177 & 0.878 \\
\hline Support -> Prop_Invest & 0.104 & 0.261 \\
\hline Prev_exp -> Prop_Invest & 0.250 & 0.011 \\
\hline
\end{tabular}




\section{Discussion of Results}

The results of the PLS analysis show that supporters of equity crowdfunding are not significantly motivated by the financial aspect (return), i.e. indicating that the single extrinsic motivator considered in this study does not influence the decision to support equity crowdfunding. On the other hand, out of the 5 intrinsic motivators, only Community is not found to be significant in influencing the decision to support. Among the intrinsic motivators, Aesthetic, Trust and Novelty are all highly significant in influencing the decision to support an equity crowdfunding venture with Aesthetic having the strongest effect.

The results of this study are contrary to that found by [19] where the study investigated two types of crowdfunding reward-based and equity-based crowdfunding. [19] find that only the financial motivator was significant in influencing the decision to invest in equity crowdfunding while nonfinancial motivators were insignificant. This result is also contrary to the findings of [49], whereby the financial motivation is found to play a dominant role in the decision to support equity crowdfunding. The financial motive being insignificant in this study suggests that supporters of equity crowdfunding in Malaysia are not traditional investors who judge an investment solely by its risk and return characteristics and this in a way is consistent with the significant negative relationship between the control variable (Prev_experience) and Prop_invest. The negative relationship suggests that the longer the duration of investment experience an individual has, the less likely he/she will invest in equity crowdfunding ventures. This could be due to the high risk of these investments as the chances of failure to realize the venture/project is high in crowdfunded ventures. It was observed earlier that it is mostly the millennials who invest in crowdfunding. Millennials are described as impact investors who are willing to support a good cause and they prefer microinvesting [21]. [3] find that small investors are more sensitive to crowdfund based on a community's needs, as compared to professional investors who crowdfund following a market logic. According to a study by Goldman Sachs in 2015, millennials are supportive of the society and environment and are more likely to accept lower return with higher risk through investments in companies that have a positive impact. The millennials are therefore more likely to support small businesses or start up entrepreneurs despite the high risk and low return, hence this supports the insignificant impact of financial value.

The non-significance of the financial motive therefore suggests that the investors in equity crowdfunding in Malaysia seem to rely less on the cognitive evaluation process and more on the affective process. The way the venture/project is presented influences the evaluation of the venture. The investors in equity crowdfunding need to know that they can trust the entrepreneur with their funds therefore the ability of the entrepreneur to create trust and maintain it improves his/her success rate of funding the projects [55] as increased trust increases the support in equity crowdfunding. Hence, the quality of information provided by the entrepreneur can improve trust and enhance the success rate of the funding [44]. The investors are also influenced by the aesthetics of the venture, i.e. how it is presented and this result is contrary to the findings of [49], whereby only financial and informational value are significant in influencing the willingness to support crowdfunding. Aesthetic value was found to be insignificant in their study. However, this confirms the suggestion by [3] that crowdfunding project developers have to strategically tailor their marketing communication plan to attract individuals to fund a project/business. The supporters are also looking for novelty in their investment. This confirms the claim by [51] that the ability to pretest a novel product may be a reason why some individuals may be willing to pledge to support crowdfunded ventures in order to be able to pretest a novel product [19]. Therefore from the results of this study, it is found that the way the venture/project is presented (aesthetics and information quality) and the newness of the venture attracts individuals to invest in equity crowdfunding ventures. Additionally, the feeling of satisfaction and enjoyment (Emotional value) from investing in the crowdfunding venture is also significant (at $5 \%$ level) in influencing the willingness to support equity crowdfunding, supporting the argument by [41] that emotional desire for experiencing positive situations increases the chance for successful crowdfunding campaigns [41].

Community is found to be insignificant possibly because the construct measures the extent to which the supporter sees himself/herself as part of the community of backers, instead of his/her contribution to the community. This result is contrary to the observation by [50] that individuals may pledge to equity crowdfunded ventures as it provides them with the perception of a shared identity.

Finally, the significantly positive relationship between the willingness to support and the proportion of an investor's portfolio likely invested in equity crowdfunding confirms the predictions of the theory of Reasoned Action [6], [28] and the Theory of Planned Behavior [4], [5] in the context of crowdfunding, i.e. support of equity crowdfunding ventures is a behavioral intention (a function of attitudes and subjective norms) that has a significant positive effect on the likelihood of the actual investment in crowdfunding.

\section{Conclusion}

This study investigates the various motivations to invest in equity crowdfunding in Malaysia. A survey questionnaire was distributed both manually and through online to individuals who had knowledge about equity crowdfunding. A final total of 195 responses were obtained out of which 169 were usable and the relationships were tested using 
SEM-PLS. Investigation into the influence of both intrinsic and extrinsic motivators on the willingness to support equity crowdfunding shows that the extrinsic motivator (financial returns) is not significant in influencing the decision but that the supporters of crowdfunding are mostly intrinsically motivated. Among the intrinsic motivators, aesthetic value, emotional value, novelty and trust are found to be highly significant. The desire to be part of a community is found to be the only intrinsic motivator that is insignificant in influencing the willingness to support equity crowdfunding. The study also finds that the willingness to support has a positive influence on the investment in equity crowdfunding. The control variable, years of investment experience, is found to have a significant negative impact on the investment in equity crowdfunding. The results of this study thus suggest that the crowd of investors in equity crowdfunding are not the typical investor who evaluate an investment based on its risk and return characteristics. Instead, the equity crowdfunding supporter uses his/her affective process rather than the cognitive decision process and is involved in equity crowdfunding because of the desire to try something new that is aesthetically appealing and can be trusted, and that which he/she can emotionally connect to. This reflects the magic of digital innovation whereby the advancement in technology has made online investing feasible with the support from investors who are influenced by their emotions and their intuition when making investing decisions.

The results are important as it highlights the new trend towards investments that resonate with investors' beliefs and ideas. This study is one of the few studies conducted in an emerging market where financial markets are at most times inefficient. Many of the results found in this study are contrary to previous studies and this could be due to the nature of the country/market in which the study is done. It could however also be simply the nature of investors supporting equity crowdfunding so it is encouraged that similar studies be carried out in other countries to confirm whether the result is due to investor trend or geographical location.

\section{Acknowledgments}

The authors would like to thank the Ministry of Higher Education, Malaysia for the support provided in funding this research under the Fundamental Research Grant Scheme (FRGS) Cycle 1/2017 [FRGS/1/2017/SS01/MMU/02/4]. The authors would also like to thank the panel of reviewers for their constructive feedback which helped improve this research paper.

\section{Website List}

Site 1: Crowdexpert.com

http://crowdexpert.com/crowdfunding-industry-statistics/

Site 2: Securities Commission Malaysia

http://www.sc.com.my

\section{References}

[1] H. Abdullah, S. Wasiuzzaman and R. Musa, University quality and emotional attachment of undergraduate students in a private higher education in Malaysia: The mediating role of total experience, International Journal of Social Economics, vol. 42, no. 7, pp. 644-665, 2015.

[2] G. K. Ahlers, D. Cumming, C. Günther, and D. Schweizer, Signaling in equity crowdfunding, Entrepreneurship Theory and Practice, vol. 39, no. 4, pp. 955-980, 2015.

[3] M. Ahsan, E. F. I. Cornelis and A. Baker, Understanding Backers' Interactions with Crowdfunding Campaigns: Co-innovators or consumers?, Journal of Research in Marketing and Entrepreneurship, vol. 20, no. 2, pp. 252272, 2018.

[4] I. Ajzen, Attitudes, Personality and Behavior. Milton Keynes: Open University Press, 1988.

[5] I. Ajzen, The theory of planned behavior, Organizational Behavior and Human Decision Processes, vol. 50, pp. 179-211, 1991.

[6] I. Ajzen and M. Fishbein, Understanding Attitudes and Pred Icting Social Behavior. Englewood Cliffs, NJ: Prentice-Hall., 1980.

[7] J. Andrews and D. C. Smith, In search of the marketing imagination: Factors affecting the creativity of marketing programs for mature products, Journal of Marketing Research, vol. 33, pp. 174-187, 1996.

[8] J. Armitage and M. Conner, Efficacy of the Theory of Planned Behaviour: A meta-analytic review, British Journal of Social Psychology, vol. 40, pp. 471-499, 2001.

[9] P. Baeck and L. Kroijer. (2016, April) Five market trends in crowdfunding for development. Nesta Website. [Online]. Available: https://www.nesta.org.uk/blog/five-market-trends-in-crowdfunding-for-development/

[10] R. A. Baron, The role of affect in the entrepreneurial process, Academy of Management Review, vol. 33, pp. 328-340, 2008.

[11] C. Barnett. (2016, September) How Millenials will change the face of finance \& investing. Forbes Website. [Online]. Available: https://www.forbes.com/sites/chancebarnett/2016/09/14/how-millennials-will-change-theface-of-finance-investing/\#62cebd57c4a9

[12] R. Baumeister and M. R. Leary, The need to belong: Desire for interpersonal attachments as a fundamental human motivation, Psychological Bulletin, vol. 117, pp. 497-529, 1995. 
[13] G. S. Becker, The Economic Approach to Human Behavior. Chicago: University of Chicago Press, 1978.

[14] M. A. Breiby and T. Slåtten, The role of aesthetic experiential qualities for tourist satisfaction and loyalty, International Journal of Culture, Tourism, and Hospitality Research, vol. 12, no. 1, pp. 1-14, 2018.

[15] U. Bretschneider, K. Knaub and E. Wieck, Motivations for crowdfunding: What drives the crowd to invest in start-ups?, in Proceedings 22nd European Conference on Information Systems (ECIS), Tel Aviv, 2014, pp. 1-12.

[16] C. Chan. (2017, October) Crowdfunding creates new opportunities in Malaysia. TMF Group Website. [Online]. Available: https://www.tmf-group.com/en/news-insights/articles/2017/october/malaysia-crowdfunding/

[17] D. Chaney, A principal-agent perspective on consumer co-production: Crowdfunding and the redefinition of consumer power, Technological Forecasting and Social Change, vol. 141, no. April, pp. 74-84, 2019.

[18] C. Cheah. (2016, July). Malaysia first in ASEAN to have crowdfunding laws. The Star Online Website. [Online]. Available: https://www.thestar.com.my/news/nation/2015/07/01/crowdfunding-laws-malaysia/?utm source=rss\& utm medium=rss

[19] M. Cholakova and B. Clarysse, Does the possibility to make equity investments in crowdfunding projects crowd out reward-based investments?, Entrepreneurship Theory and Practice, vol. 39, no. 1, pp. 145-172, 2015.

[20] K. G. Choo and R. Madden, Crowdfunding Malaysia's sharing economy: Alternative financing for micro, small and medium enterprises, Kuala Lumpur, Malaysia, 2017.

[21] B., Clark. (2018, March) Why aren't millenials investing? Microventures Website. [Online]. Available: https://microventures.com/why-arent-millennials-investing

[22] P. S. Cooper and D.R. Schindler, Business Research Methods, 12th edition. Chicago: McGraw- Hill International Editions, 2013.

[23] M. Csikszentmihalyi, Creativity: Flow and the Psychology of Discovery and Invention. New York: Harper Perennial, 1996.

[24] R. deCharms, Personal Causation. New York: Academic Press, 1968.

[25] E. Deci and R. Ryan, Intrinsic Motivation and Self-Determination in Human Behavior. New York: Penguin, 1985.

[26] S. Estrin, D. Gozman, and S. Khavul, The evolution and adoption of equity crowdfunding: Entrepreneur and investor entry into a new market, Small Business Economics, vol. 51, no. 2, pp. 425-439, 2018.

[27] A. Field, Discovering Statistics Using SPSS, 3rd ed. London: Sage Publications, 2009.

[28] M. Fishbein and I. Ajzen, Belief, Attitude, Intention and Behavior: An Introduction to Theory and Research. Reading, MA: Addison-Wesley, 1975.

[29] C. Fornell and D. F. Larcker, Evaluating structural equation models with unobservable variables and measurement error, Journal of Marketing Research, vol. 18, no. 1, pp. 39-50, 1981.

[30] R. Foxall and R. E. Goldsmith, Consumer Psychology for Marketing. London: Routledge, 1994.

[31] J. J. Furedy and D. M. Riley, Human Pavlovian autonomic conditioning and the cognitive paradigm, in Cognitive Processes and Pavlovian Conditioning in Humans (G. Davey, Ed.). Chichester: John Wiley \& Sons, 1987, pp. $1-25$.

[32] D. Gefen, D. Straub and M. C. Boudreau, Structural equation modeling techniques and regression: Guidelines for research practice, Communications of the Association for Information Systems, vol. 4, no. 7, pp. 2-77, 2000.

[33] E. Gerber and J. Hui, Crowdfunding: Motivations and deterrents for participation, ACM Transactions in Computer-Human Interaction, vol. 20, no. 34, pp. 1-32, 2013

[34] A. Godoroja and S. Lund-Jensen, Equity Crowdfunding: Identifying success drivers for a new financing model, M.Sc. thesis, Stockholm School of Economics, Stockholm, Sweden, 2014.

[35] J. F. Hair, W. C. Black, B. J. Babin, and R. E. Anderson, Multivariate Data Analysis: A Global Perspective, 7th ed. New Jersey: Pearson Prentice Hall, 2010.

[36] M. Harms. (2007, July) What drives motivation to participate financially in a crowdfunding community? SSRN Website. [Online]. Available: https://papers.ssrn.com/sol3/papers.cfm?abstract id=2269242.

[37] S. Harter, Effectance motivation reconsidered: Toward a developmental model, Human Development, vol. 1, pp. 661-669, 1978.

[38] F. Hervé, E. Manthé, A. Sannajust, and A. Schwienbacher. (2016, January) Investor Motivations in investmentbased crowdfunding. Researchgate Website. [Online]. Available: https://www.researchgate.net/publication/315 029809 Investor Motivations in Investment-Based Crowdfunding.

[39] F. Hervé and A. Schwienbacher, Round-number bias in investment: Evidence from equity crowdfunding, Finance, vol. 39, no. 1, pp. 71-105, 2018

[40] M. B. Holbrook, Special session summary. Customer value-A framework for analysis and research, Advances in Consumer Research, vol. 23, no. 2, pp. 138-142, 1996.

[41] C. Hopp, J. Kaminski and F. Piller, Accentuating lead user entrepreneur characteristics in crowdfunding campaigns - The role of personal affection and the capitalization of positive events, Journal of Business Venturing, vol. 11, p. e00106, 2019.

[42] L. Hornuf and A. Schwienbacher, Market mechanisms and funding dynamics in equity crowdfunding, Journal of Corporate Finance, vol. 50, no. June, pp. 556-574, 2018.

[43] L. Hu and P. M. Bentler, Cutoff criteria for fit indexes in covariance structure analysis: Conventional criteria versus new alternatives, Strudtural Equation Modeling: A Multidisciplinary Journal, vol. 6, no. 1, pp. 1-55, 1999.

[44] J. A. Koch and M. Siering, Crowdfunding success factors: The characteristics of successfully funded projects on crowdfunding platform, in Proceedings 23rd European Conference on Information Systems (ECIS 2015), Munster, 2015.

[45] R. Kotha and G. George, Friends, family, or fools: Entrepreneur experience and its implications for equity distribution and resource mobilization, Journal of Business Venturing, vol. 27, no. 5, pp. 525-543, 2012. 
[46] I. Kukkonen, E. Åberg, O. Sarpila, and T. Pajunen, Exploitation of aesthetic capital - disapproved by whom?, International Journal of Sociology and Social Policy, vol. 38, no. 3-4, pp. 312-328, 2018.

[47] B. Littlewood, M. Neil and G. Ostrolenk, The role of models in managing the uncertainty of software-intensive systems, Reliability Engineering \& System, vol. 50, no. 1, pp. 87-95, 1995.

[48] A. Majumdar and I. Bose, My words for your pizza: An analysis of persuasive narratives in online crowdfunding, Information and Management, vol. 55, no. 6, pp. 781-794, 2018.

[49] K. Moysidou and S. Spaeth, Cognition, emotion and perceived values in crowdfunding decision making, presented at the 14th International Open and User Innovation Conference, Harvard, Boston, August 1-3, 2016, Paper OUI-52 MATr1B.09.

[50] A. M. J. Muniz and T. C. O'Guinn, Brand community, Journal of Consumer Research, vol. 27, pp. 412-432, 2001.

[51] A. Ordanini, L. Miceli, M. Pizzetti, and A. Parasuraman, Crowd-funding: Transforming customers into investors through innovative service platforms, Journal of Service Management, vol. 22, pp. 443-470, 2011.

[52] P. M. Podsakoff, S. B. MacKenzie, J.-Y. Lee, and N. P. Podsakoff, Common method biases in behavioral research: A critical review of the literature and recommended remedies, Journal of Applied Psychology, vol. 88, no. 5 , pp. $879-903,2003$.

[53] R. M. Ryan and E. L. Deci, Intrinsic and extrinsic motivations: Classic definitions and new directions, Contemporary Educational Psychology, vol. 25, pp. 54-67, 2000.

[54] A. Schwienbacher and B. Larralde, Crowdfunding of small entrepreneurial ventures, in The Oxford Handbook of Entrepreneurial Finance (D. Cumming, Ed.). New York: Oxford University Press, 2012, pp. 369-391.

[55] V. Shankar, G. L. Urban and F. Sultan, Online trust: a stakeholder perspectives, concepts, implications and future directions, Journal of Strategic Information Systems, vol. 11, no. 3-4, pp. 325-344, 2002.

[56] J. N. Sheth, B. I. Newman and B. L. Gross, Why we buy what we buy: A theory of consumption values, Journal of Business Research, vol. 22, no. 2, pp. 159-170, 1991.

[57] K. K. Sidhu. (2018, November) Equity crowdfunding report card for Malaysia in 2018. Digital News Asia Website. [Online]. Available: https://www.digitalnewsasia.com/digital-economy/equity-crowdfunding-report-cardmalaysia-2018

[58] Slice Capital. (2018, March) The future of investing in startups: Equity crowdfunding. Medium Website. [Online]. Available: https://medium.com/@SliceCapital/the-future-of-investing-in-startups-equity-crowdfunding-9ec3fec16 $\mathrm{c} 44$

[59] J. P. Stevens, Applied Multivariate Statistics for the Social Sciences, 2nd Editio. New Jersey: L. Erlbaum Associates, 1992.

[60] B. Twoon and J. Chow. (2016, January) The equity crowdfunding bandwagon: South east Asia jumps on board. Crowdfund Insider Website. [Online]. Available: https://www.crowdfundinsider.com/2016/01/80077-the-equitycrowdfunding-bandwagon-south-east-asia-jumps-on-board/

[61] T. Ward, Cognition, creativity, and entrepreneurship, Journal of Business Venturing, vol. 10, pp. 173-188, 2004.

[62] S. Wasiuzzaman and N. Nurdin, Debt financing decisions of SMEs in emerging markets: Empirical evidence from Malaysia, International Journal of Bank Marketing, vol. 37, no. 1, pp. 258-277, 2019

[63] P. L. Yu, M. Balaji and K. W. Khong, Building trust in internet banking: A trustworthiness perspective, Industrial Management \& Data Systems, vol. 115, no. 2, pp. 235-252, 2015. 